\title{
Verbum
}

$29(2016)$ 149-171

Ks. Mateusz Targoński

\section{ŚwIATŁOŚĆ BożEGO MIESZKANIA WEDŁUG PISM QUMRAŃSKICH W KONTEKŚCIE TRADYCJI BIBLIJNEJ I APOKRYFICZNEJ}

The Light of God's Dwelling according to Qumran

Writings, in the ConteXt of Biblical and Apocryphal Tradition

STRESZCZENIE

Artykuł ukazuje sposób, w jaki obraz światła jest używany do opisania Bożego mieszkania w pismach pochodzących ze wspólnoty qumrańskiej. Pierwsza jego część kreśli tło zawarte w Biblii Hebrajskiej, pozwalające zrozumieć fundament, na którym była budowana teologia judaizmu drugiej świątyni. Druga część analizuje najważniejsze teksty niekanoniczne, które silnie oddziaływały na teologię wspólnoty z Qumran: 1 Ksiegę Henocha oraz Ksiege Jubileuszów. Ostatnia część analizuje teksty pochodzące znad Morza Martwego, opisujące światłość Bożego mieszkania: Pieśni Ofiary Szabatowej, Btogostawieństwa i przekleństwa, Pieśn Mędrca oraz Dzieta Boże. Wskazane są również przykłady nawiązań o charakterze eschatologicznym w innych tekstach wspólnoty. Światło użyte do opisu miejsca przebywania Boga podkreśla przede wszystkim doskonałość niebiańskiego pałacu
SŁOWA KLUCZE

Światło;

mieszkanie Boga;

niebo;

Qumran 
oraz niedostępność Stwórcy dla człowieka w czasie jego ziemskiego życia.

The article explores the ways in which the Light; writings of the Qumran community use the metaphor of light to describe God's dwelling. The first part outlines the background conGod's dwelling; heaven; tained in the Hebrew Bible, which permits Qumran an understanding of the theological foundations of Judaism in the Second Temple period. The second part considers the two important non-canonical texts of greatest importance to the Qumran community, namely First Book of Enoch and Book of Jubilees. The last part analyses the four Qumran sectarian works which employ the "light of God's dwelling" imagery: Songs of Sabbath Sacrifice, Blessings and Curses, Songs of the Maskil and Works of God. Also examined are examples of the broader eschatological use of light in other texts of the community. Light, when used to describe God's dwelling, emphasises the perfection of a heavenly palace and the unapproachability of the Creator by the man during his earthly lifetime.

Autor Pierwszego Listu do Tymoteusza w zawartej tam doksologii charakteryzuje Boga jako tego, który „zamieszkuje światłość niedostępną" (1 Tm 6,16). Cały werset, mający cechy tekstu liturgicznego, łączy w sobie inspiracje biblijne $z$ hellenistycznym sposobem wyrażania ${ }^{1}$. Niedostępność

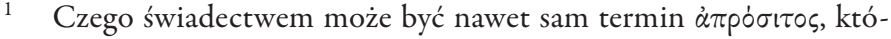
ry jest hapax legomenon nie tylko w Nowym Testamencie, ale też 
Boga i miejsca Jego zamieszkania jest elementem często pojawiającym się na kartach Pisma Swiętego. Rodzi się jednak pytanie, skąd zaczerpnięta jest myśl o Bogu, który zamieszkuje światłość, i szerzej - jaka jest relacja pomiędzy Bogiem a światłością. Odnalezione na Pustyni Judzkiej zwoje ukryte przez wspólnotę qumrańską wielok rotnie odwołują się do metafory światła. Celem niniejszego artykułu będzie wskazanie i przeanalizowanie na tle wcześniejszego kontekstu tych spośród tekstów, które łączą mieszkanie Boga ze światłością. Ich analiza i porównanie może okazać się pomocą w lepszym zrozumieniu orędzia Nowego Testamentu, chociaż pełna odpowiedź na pytanie o zaplecze pojęciowe przywołanego cytatu wymagałaby znacznie szerszego studium.

\section{Teo starotestamentalne}

Aby uzyskać pełen obraz, należy rozpocząć od krótkiego nakreślenia perspektywy, jaka rysuje się w Biblii Hebrajskiej, stanowiącej podstawowe podłoże dla refleksji teologicznej zawartej w pismach judaizmu Drugiej Świątyni. Izraelici byli świadomi, że żadna rzeczywistość stworzona, nawet „niebo i niebiosa najwyższe”, nie jest w stanie objąć swojego Stwórcy. Znalazło to wyraz w modlitwie Salomona (1 Krl 8,27; 2 Krn 6,18). Wprawdzie prorockie wypowiedzi Trito-Izajasza (Iz 66,1) i Jeremiasza (Jr 23,24) mówią o Bogu „wypełniającym niebo i ziemię", jednak mają one na celu raczej podkreślenie nieograniczoności Pana niż możliwości zamknięcia go w ramach świata stworzonego. Naturalną konsekwencją takiego stanu rzeczy jest brak jakiejkolwiek możliwości ukrycia się przed Najwyższym, z czego zdawał sobie sprawę zarówno psalmista (Ps 139,7-12), jak i prorok Amos (Am 9,23). Ta wszechobecność Boga nadaje jednocześnie sens budowie

w Septuagincie, natomiast znany jest np. z Geografii Strabona czy

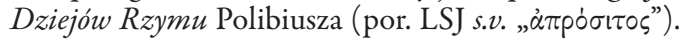


świątyni, której podjął się Salomon - chociaż jest ona zbyt mała, by mogła objąć Stwórcę (1 Krl 8,27), to jednak Jego oczy będą na nią nieustannie skierowane, co więcej, w niej zamieszka Imię Pana $(8,29)$.

Zamieszkanie bóstwa w uprzywilejowanych miejscach stanowiło zwyczajowy element wierzeń ludów ościennych, czego wyraz możemy znaleźć również w cyklu o Jakubie, gdy ten o miejscu swojego odpoczynku mówi: „prawdziwie jest to dom Boga i brama do nieba” ( $\mathrm{Rdz} 28,17)$. W wypowiedzi tej patriarcha nazywa Betel „domem Boga”, uzasadniając w ten sposób jego nazwę, ale jednocześnie daje wyraz przekonaniu, że prawdziwym miejscem zamieszkania Stwórcy jest niebo, do którego Betel może być jedynie bramą. Zatem, mimo przekonania o wszechobecności Pana, za miejsce Jego zamieszkania uznawane są niebiosa, co od różnia Go od bóstw pogańskich. Szczególnie często podkreślane jest to w psalmach, które w niebie widzą miejsce przebywania nie tylko Boga, ale również Jego tronu ${ }^{2}$. Taka lokalizacja miejsca przebywania Boga jest tak powszechna, że wyrażenie "mieszkający w niebie” (Ps 2,4) staje się synonimem tytułu „Pan”, co podkreśla użyty w tym wersecie paralelizm. Zatem próba scharakteryzowania Bożego mieszkania będzie wiązała się przede wszystkim $\mathrm{z}$ ustaleniem cech, jakie są przypisywanie samym niebiosom.

Biblia Hebrajska i wywodząca się z niej tradycja dalekie są od stwierdzenia „Bóg jest światłością”, które można odnaleźć na kartach Pierwszego Listu św. Jana $(1 \mathrm{~J} 1,5)^{3}$. Owszem, światłość ma w przeważającej mierze pozytywny wydźwięk, jednak jest ona dziełem Boga, stworzeniem, które rozpoczyna cały tydzień kształtowania wszechświata, zgodnie z opisem Heksameronu (Rdz 1,2). Jego lektura pozwala dostrzec jeszcze jedną istotną cechę interesującej nas rzeczywistości: chociaż zostaje ona przez Boga nazwana „dniem”, to jed-

2 Zob. np. Ps 11,4; 14,2; 20,7; 33,1314; 53,3; 76,9; 80,15; 102,20; 103,19; 104,2-3; 113,56; 115,3; 123,1.

3 Por. Parchem, Ksiega Daniela, 211. 
nak nie jest powiązana ze słońcem ani pozostałymi ciałami niebieskimi, które zostaną stworzone dopiero w czwartym dniu ( $\operatorname{Rdz} 1,1418)^{4}$. Ważną z punktu widzenia niniejszej analizy wzmiankę znajdujemy również w Księdze Hioba, gdzie autor sugeruje istnienie mieszkania, do którego wraz z nastaniem nocy powraca światło, podobnie zresztą, jak dzieje się z ciemnością w ciągu dnia (Hi 38,19). Zbliżonego obrazu używa również psalmista, mówiąc o namiocie, jaki na krańcu świata zamieszkuje słońce (Ps 19,57).

Jednak poza wielokrotnym użyciem terminu „światło” do opisania rzeczywistości naturalnej Stary Testament chętnie odwołuje się do niego, by wyrazić pewną symbolikę. W ten sposób światło staje się symbolem życia, wyrażenie „oglądać światło” oznacza „żyć” , zaś „światło oczu” to symbol ludzkiej witalności ${ }^{6}$. Wiele tekstów używa go jako symbolu wybawienia i pomyślności, które najczęściej są powiązane z działaniem Boga w życiu człowieka7. W tej samej szerokiej grupie znaczeniowej należałoby zapewne szukać odniesień do światła jako do mądrości ${ }^{8}$, postępowania zgodnego z normami etycznymi ${ }^{9}$ czy wreszcie sprawiedliwości ${ }^{10}$. Przez analogię ciemność niejednokrotnie ma znaczenie przeciwne, co w judaizmie okresu drugiej świątyni, w szczególności we wspólnocie qumrańskiej czy niektórych tekstach Nowego Testamentu, przyjmie postać wyraźnego dualizmu, który nie ogranicza się jedynie do płaszczyzny etycznej ${ }^{11}$.

4 Dalsze potwierdzenie niezależności światła od słońca można znaleźć w TDOT I s.v. „אוֹ 'ôr", 151-153.

5 Zob. Hi 3,16; 33,28; Ps 36,10; 49,20; 58,9; Koh 6,5.

6 Zob. 1 Sm 14,27.29; Ezd 9,8; Ps 13,4; 19,9; 38,11; Prz 15,30; 29,13 (zwłaszcza zestawiony z 22,2).

7 Zob. np. Est 8,16; Hi 18,18; 22,28; Ps 18,29; 97,11; Prz 13,9; Iz 9,1; 49,$6 ; 58,8$.

8 Zob. Hi 12,22; Ps 19,9; 119,105.130; Prz 6,23; Koh 2,13; 8,1.

9 Zob. Hi 24,13-17; 25,5; Ps 11,2; Prz 7,9; Iz 5,20.

10 Zob. Ps 37,6; Mi 7,9; So 3,5.

11 Najważniejsze cechy paradygmatu dualistycznego podaje np. Wróbel, Studia, 35. 
Ostatnim pytaniem, jakie należy w tym miejscu postawić, jest relacja światła do Boga. Wydaje się, że Biblia Hebrajska rygorystycznie przestrzega rozróżnienia JHWH - Stwórca i światłość - stworzenie. Tego faktu nie niweczą wspomniane powyżej teksty mówiące metaforycznie o „światłości Bożego oblicza" i świetle, jakim jest Bóg dla wiernego. Patrząc na starotestamentalne teofanie, można dostrzec, że światło jest w nich niemal nieobecne. Bóg najczęściej objawia się w postaci obłoku, dymu i ognia ${ }^{12}$, o którym jednak tylko w przypadku ognistego słupa prowadzącego Izraelitów przez pustynię, Biblia stwierdza, że świeci. Dopiero Ezechiel i Habakuk wyraźnie łączą chwałę objawiającego się Boga ze światłem ${ }^{13}$, podobne sformułowanie przekazuje również psalmista, mówiący o Bogu, który jest „światłem okryty jak płaszczem” (Ps 104,2a). Ten ostatni tekst jest szczególnie zastanawiający, gdyż brak w nim kontekstu epifanii, stąd też może być on pierwszym źródłem mówiącym o światłości jako o własnym atrybucie Boga, wyrażającym Jego transcendencję ${ }^{14}$. Bezpośredni kontekst poprzedzający ten stych wiąże światło ze „wspaniałością i majestatem" (w. 1c), które również stanowią Boże odzienie. Z kolei w drugiej części tego wersetu można odnaleźć paralelizm pomiędzy światłością a niebiosami, które tworzą „namiot”, albo raczej „zasłonę”, podobną do tej, jaka znajdowała się w Przybytku. To sformułowanie może wiązać się z przekonaniem, że niebiosa stanowią szatę Boga ${ }^{15}$, co znajduje swój

12 Zob. np. Wj 3,2; 13,21-22; 19,16; 24,16-17; Pwt 1,33; 4,11-12; 5,22-23; 1 Krl 19,11-12. Rzeczywistość boska jest ukazywana za pomocą obrazu ognia nie tylko w tradycji biblijnej, ale też na Bliskim Wschodzie (Fenicja, Ugarit). Por. Davila, Liturgical Works, 130.

13 Ez 1,4.13.27-28; 10,4; 43,2; Ha 3,4. Warto przy tych tekstach zwrócić uwagę na to, że znacznie częściej niż typowego terminu אוֹ prorocy na opisanie chwały Pana używają określenia נגֵֵ , które odnosi się nie tyle do źródła światła, ile do samego blasku emanującego z niego (por.

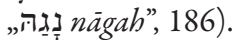

14 Por. Łach, Ksiega Psalmów, 443.

15 Por. „רוֹ 'ôr", 164. 
wyraz m.in. w Ps 102,26-27, który zawiera również wydźwięk eschatologiczny.

Dalsze poszukiwanie związków Boga i Jego mieszkania ze światłością, już poza kontekstem epifanii, z konieczności musi prowadzić do tekstów o charakterze apokaliptycznym i eschatologicznym, gdyż to one są w stanie ukazać Stwórcę w Jego „naturalnym środowisku”. W Biblii Hebrajskiej eschatologiczne określenie Boga jako światłości odnowionej Jerozolimy napotykamy u Trito-Izajasza, który zapowiada: "JHWH ci będzie światłością wieczną" (Iz 60,19) ${ }^{16}$. Drugim tekstem, na który należy zwrócić w tym miejscu uwagę, jest fragment doksologii, jaką Daniel wysławia Boga, mówiąc, że „światłość mieszka z Nim” (Dn 2,22). Nie znajdujemy więc tutaj charakterystyki samych niebios, lecz zostają one utożsamione z miejscem, w którym zamieszkuje światłość. Jednak kontekst nakazuje dostrzec tutaj przede wszystkim metaforyczne znaczenie tego terminu, odnoszącego się do mądrości pochodzącej od Boga, a udzielonej Danielowi, która zdolna jest przeniknąć ciemność tajemnic niedostępnych człowiekowi ${ }^{17}$. Jest to tym bardziej zasadne, że forma zbliżona do użytego w tym miejscu aramejskiego rzeczownika נְהִיר (będącego hapax legomenon), נַהִירו, pojawia się w tej księdze jedynie w dwóch innych miejscach (Dn 5,11.14) ${ }^{18}$,

16 Podobne sformułowania odnajdziemy w tej samej części księgi (Iz 60,1-3; 62,1-2), jednak większość z nich odnosi się prawdopodobnie do obrazu światła jako symbolu zbawienia i pomyślności, znanego z innych miejsc Starego Testamentu. Nie ulega jednak wątpliwości, że przynajmniej dwukrotnie $(60,2.19)$ światłość wiąże się bezpośrednio z JHWH.

17 Por. Homerski, Księga Daniela, 71, który obok wątku mądrościowego dostrzega tutaj „porównanie Boga i Jego mieszkania do światłości”. Inne przykłady tekstów ukazujących światłość jako symbol mądrości można znaleźć w przypisie 8.

18 Zbliżonych form brak jest również jakichkolwiek innych tekstach aramejskich Biblii Hebrajskiej. Bezpośredni hebrajski odpowiednik נִ נְרָָרה pojawia się jeden raz w Księdze Hioba $(3,4)$ na określenie światła dnia. Parchem (Biblijny jezzyk aramejski, 356) interpretuje נַהִ jako „światło, oświecenie [umysłu]”. 
gdzie również jest użyta jako metafora mądrości, jaka została udzielona człowiekowi.

\section{TEKsty POZABIBLIJNE}

Na podstawie rękopisów odnalezionych w Qumran wiemy, że wspólnota tam mieszkająca znała i wykorzystywała wiele tekstów nieznajdujących się we współczesnym kanonie Biblii Hebrajskiej, gdyż w okresie zamieszkania osady nie istniał jeszcze ustalony kanon ksiąg świętych, zwłaszcza w odniesieniu do Pism. Dlatego też wśród manuskryptów odnalezionych na Pustyni Judzkiej więcej jest kopii niektórych tekstów apokryficznych niż rękopisów wielu ksiąg zaliczanych dzisiaj do Starego Testamentu, co może świadczyć o ich dużym wpływie na myśl teologiczną wspólnoty qumrańskiej. Wśród nich największą rolę odgrywają dwa teksty, które były znane w przekładach jeszcze przed odkryciami na Pustyni Judzkiej: Pierwsza Księga Henocha i Księga Jubileuszów ${ }^{19}$.

Ten drugi tekst, będący parafrazą historii zbawienia od stworzenia świata do wyjścia z Egiptu, pochodzi z II w. przed Chr. i wykazuje wiele związków z innymi utworami o podobnej tematyce powstałymi w tamtej epoce. Szczególnie istotny z punktu widzenia niniejszej analizy jest jego wpływ na wspólnotę qumrańską, a ten trudno zakwestionować, biorąc pod uwagę odnalezienie w grotach czternastu jego rękopisów ${ }^{20}$. Co więcej, Księga Jubileuszów prawdopodobnie jest cytowana przez

19 Pokrewieństwo teologiczne tych dzieł z tekstami wspólnoty wskazuje m.in. Newsom, „Sectually Explicit”, 169, 175.

20 VanderKam we wprowadzeniu do krytycznej edycji tekstu apokryfu (The Book of Jubilees, IX) pisze jeszcze o trzynastu rękopisach, później jednak aktualizuje tę informację na czternaście (zaznaczając istnienie jeszcze jednego niejasnego rękopisu, por. VanderKam, „Book of Jubilees”, 435), co potwierdza Muchowski w pierwszym wydaniu Komentarzy, zaś w drugim pisze o jeszcze większej ich liczbie (Komentarze, 242). 
tekst 4Q228 przy użyciu tej samej formuły, jaka była używana do wprowadzania cytatów biblijnych (כי כן כתוב במחלקות; 4Q228 I 1,9)21 zaś Dokument Damasceński powołuje się na Ksiegepodziatu czasów wedtug ich jubileuszy i ich tygodni (ספר מחלקות העתים ליובליהם ובשבועותיהם; CD 16,3-4), utożsamianą najczęściej z omawianym utworem. Także szereg związków teologicznych i terminologicznych występujących pomiędzy tym apokryfem a tekstami wspólnoty potwierdza istniejącą między nimi zależność22.

Pomimo częściowo apokaliptycznego charakteru ${ }^{23}$ tekst nie wnosi wiele informacji do badanego przez nas zagadnienia. W opisie teofanii na Synaju chwała JHWH opisana jest jako „ogień płonący" (כאש בוערת; Jub 1,3), co pozostaje w zgodzie z tekstem Wj 24,17, stanowiącym podstawę parafrazy. Odnośnie do samego zamieszkania Boga, jedyna informacja, jaką znajdujemy w tekście apokryfu, zawarta jest w zapowiedzi czasów ostatecznych: „zstąpię i zamieszkam z nimi na wszystkie wieki wieków" (ארד ושכנתי עמם בכול עולמי עולמים; Jub 1,26). Nieliczne opisy eschatologiczne mówią również o mającym nastąpić wtedy „odnowieniu światel” $(1,29 ; 19,25)$. Możliwe, że teksty te stanowią odbicie przepowiedni Trito-Izajasza, dotyczących odnowienia Jerozolimy ${ }^{24}$ i odwołują się jednocześnie do oczekiwania czasów ostatecznych jako momentu nowego stworzenia $(1,29)$. Nie ma jednak bezpośredniego powiązania pomiędzy zapowiedzią zamieszkania Boga i mającym nastąpić odnowieniem światel, poza wspólnym umiejscowieniem ich w perspektywie eschatologicznej.

\footnotetext{
21 Por. Szymik, „Qumran a kanon”, 84.

22 Por. Segal, The Book of Jubilees, 2.

23 Por. VanderKam, „Reflections”, 21-22.

24 Taką interpretację mocno wspiera wzmianka o odbudowaniu świątyni w Jerozolimie (Jub 1,29) wprost powiązana z odnowieniem świateł, które jednak ma raczej charakter kosmiczny, związany z odnowieniem całego stworzenia. Związki tego fragmentu z Trito-Izajaszem wskazuje np. Scott, On Earth, 124, 126.
} 
Dla przeprowadzanej analizy znacznie istotniejszym źródłem pozabiblijnym jest Pierwsza Ksiegga Henocha. W znanej dzisiaj postaci zachowała się w całości jedynie w języku etiopskim, podczas gdy oryginal został spisany prawdopodobnie w języku aramejskim, w którym zachowały się liczne fragmenty odnalezione w Qumran. Księga ma charakter złożony, obecnie stanowi kompozycję pięciu niezależnych dzieł: Księga Czuwajacych, Księga Przypowieści, Ksiega Astronomiczna, Ksiega Snów oraz List Henocha. Na Pustyni Judzkiej nie odnaleziono tekstu drugiej części, która powstała prawdopodobnie pod koniec I w. po Chr. - jej miejsce w korpusie pierwotnie zajmowała prawdopodobnie Ksiega Gigantów, poświadczona przez wiele rękopisów qumrańskich ${ }^{25}$.

Najstarsza część, Księga Astronomiczna (1 He 72-82), w wersji qumrańskiej (4Q208-211) przekazana została w redakcji bardziej rozbudowanej niż w tekście etiopskim ${ }^{26}$, nie przekazuje informacji, które mogłyby posłużyć w niniejszej analizie, gdyż „światło” odnosi się tam przede wszystkim do ciał niebieskich.

Niezwykle istotnym tekstem jest natomiast opis Bożego pałacu (14,8-23), zawarty w drugiej (pod względem daty powstania) Księdze Czuwajacych (1 He 1-36). Jest on poświadczony również przez aramejski rękopis z Qumran (4Q204). We fragmencie tym opisane są dwa budynki, z których pierwszy zbudowany jest z ognia, gradu i śniegu, zaś drugi - właściwe miejsce zamieszkania Boga - wyłącznie z ognia. W jego centrum znajduje się „wysoki tron” (כרסא רם) który wyglądał ,jak kryształ/lód, a koła jego jak koło słońca" (כזכוכי וגלגלוהי כגלגל שמשא; 1 He 14,18). O samym Zasiadającym Henoch pisze, że „Jego szata była jaśniejsza od

25 Por. Rubinkiewicz, Apokryfy, 143.

26 Por. Muchowski, Komentarze, 268.

27 Problemem w odtworzeniu aramejskiego tekstu Ksiegi Henocha jest zły stan rękopisów qumrańskich. Tekst przytoczony w artykule bardzo często bazuje na rekonstrukcjach dokonanych przez Milika (The Books of Enoch). 
słońca i bielsza od śniegu" (ללבושה נהיר מן שמשא וחור מן תלגא; $1 \mathrm{He}$ 14,20). Opisy te sugerują również powiązanie pomiędzy niebiańskim pałacem a świątynią ${ }^{28}$, zaś blask światłości obecny w komnacie tronowej podkreśla, że bóstwo jest niedostępne dla ludzkiego wzroku ${ }^{29}$. W tekście tym do opisu samego Boga i jego otoczenia wykorzystana jest metafora światła, chociaż znacznie większa rola przypisana jest w tekście ogniowi. Pojawia się on również w opisie zawartym w rozdziałach 24-25, gdzie Henoch widzi tron, na którym zasiądzie Pan w czasach ostatecznych. Patriarcha nie dostrzega tam obecności Boga, a mimo to zauważa górę, która dzień i noc płonie ogniem. W kontekście Ksiegi Czuwających warto zwrócić jeszcze uwagę na przesłanki odnoszące się do czasów ostatecznych, kiedy to „wybrani otrzymają światło” $(5,7)$ oraz „światło Boże będzie świecić nad nimi” $(1,8)$, podobnie jak miało to miejsce we wcześniej przywołanych tekstach o charakterze apokaliptycznym.

Apokaliptyczna Księga Snów (1 He 83-90), której fragmenty znajdują się w czterech manuskryptach (4Q204-207), w zawartych w niej symbolicznych opisach teofanii związanych z Exodusem $(89,22.30)$ nie odwołuje się do obrazów światła, ciemności ani ognia. Warto zwrócić w tym tekście uwagę na wzmiankę o eschatologicznym zamieszkaniu Boga pośrodku Nowej Jerozolimy $(90,29)$, która staje się w ten sposób miejscem przebywania „Pana owiec”, jak określany jest w utworze JHWH.

W stanowiącym zwieńczenie całego pięcioksięgu Liście Henocha (1 He 91-104; fragmenty w Qumran 4Q204 i 4Q212) światło kilkakrotnie użyte jest jako obraz przyszłej nagrody sprawiedliwych ${ }^{30}$, z kolei los niegodziwych ukazany jest jako ciemność i płomienie ${ }^{31}$. Stwórca zapowiada: „wprowadzę do jaśniejącego światła tych, którzy miłują

28 Por. Newsom, „Heaven”, 338; Collins, Apocalypticism, 133.

29 Por. Stokes, „Throne Visions”, 352.

30 Zob. $1 \mathrm{He}$ 92,4; 96,3; 104,2; 108,12-15.

31 Zob. 1 He 92,5; 100,9; 102,1; 103,8; 108,3-5.14. 
moje święte imię" $(108,12)$, co pozwala wnioskować o miejscu wiecznej nagrody, która często wiązana jest z przebywaniem w obecności Boga.

Znacznie późniejsza Księga Przypowieści (1 He 37-71) wykracza oczywiście poza zakres zainteresowania tego artykułu, zaś w Księdze Gigantów brak jest odwołań do światła, które mogłyby wnieść nowe dane do omawianego zagadnienia. Warto podkreślić, że cały Corpus Henochicum jest istotnym źródłem, które kreśli wyraźny i sugestywny obraz Bożego mieszkania, zwłaszcza w opisie niebiańskiego pałacu. Siła jego oddziaływania miała niewątpliwie wpływ na kształtowanie się teologii wspólnoty qumrańskiej, pozostałych nurtów powstałych w obrębie judaizmu drugiej świątyni, a także chrześcijaństwa.

\section{Teksty WŁasne wspólnoty}

W tej sytuacji może zaskakiwać fakt, że qumrańczycy, chętnie studiujący Księge Henocha i często określani przez współczesnych naukowców jako wspólnota apokaliptyczna, przywiązywali niewielką wagę do opisu niebios jako miejsca zamieszkania Boga ${ }^{32}$. W'śród utworów należących do grupy qumrańskiej najistotniejszym dla analizowanego zagadnienia jest zbiór Pieśni Ofiary Szabatowej ${ }^{33}$, na który składa się dziewięć rękopisów znalezionych w Qumran (4Q400-

32

33 Oczywiście przy założeniu, że rzeczywiście pochodzi on od qumrańczyków. Jest ono uzasadnione liczbą rękopisów, użyciem słownictwa typowego dla wspólnoty i podobieństwem teologicznym z innymi tekstami (taką opinię prezentuje m.in. Muchowski, Komentarze, 171-172). Nie brakuje badaczy odrzucających tezę o "sekciarskim” pochodzeniu Pieśni (zob. Newsom, „Sectually Explicit”, 179-185 oraz Chazon, „Prayer”, 46), jednak oni również uznają ich bliską zależność i duże znaczenie we wspólnocie. Dyskusję na ten temat streszcza m.in. Collins, Apocalypticism, 141-143. 
407; 11Q17) oraz jeden odnaleziony na Masadzie (Masada ShirShabb I-II lub Mas1k). Jak zauważa Muchowski, kompozycja ta ,jest najstarszym pobiblijnym tekstem o cechach mistycznych i ezoterycznych, dokumentującym żydowskie tradycje związane z wyglądem nieba i jego mieszkańcami" ${ }^{34}$. Najstarsze jego rękopisy są datowane na lata 75-50 przed Chr., co wyznacza terminus ad quem powstania utworu, noszącego wyraźnie liturgiczny charakter. Liczba rękopisów świadczy o jego dużym znaczeniu we wspólnocie, natomiast znalezienie kopii na Masadzie może być dowodem jego rozpowszechnienia także poza zamkniętą grupą qumrańską.

W zachowanym tekście wielokrotnie opisywani są mieszkańcy niebiańskiego dworu, tj. różne kategorie duchów (רוח), z których wiele określanych jest także terminem „bogowie” (אלהים). Do ich opisu kilkakrotnie używany jest ogień: „o postaciach węgli ognistych" (במרים גחלי אש: 4Q403 I 2,635), „kształty płomienia ognia” (בדני להבת אשי אש: 4Q403 I 2,9), ,jak

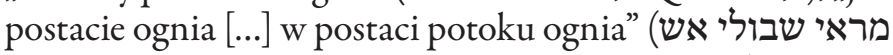
[...] כמראי אש; 4Q405 XX 2 + XXI-XXII,10). Jednak znacznie częściej ich postać ukazywana jest jako świetlista: „duchowe świetliste kształty [...] kształty światła chwały” (בדני רוח אורים [...] בדני אור כבוד); 4Q405 XIV-XV 1,5), „koła ${ }^{36}$ świetliste” (אבופי אורני אורים; 4Q405 XX 2 + XXI-XXII,3 = 11Q17 XVI-XVII 7,4), ,kolory najświętszego duchowego światła" (צעי אור רוח קודש קדשים; 4Q405 XXIII 2,8),

34 Muchowski, Komentarze, 171. Jak zauważa Zdun w swoim thumaczeniu, opisy nieba zawarte w utworze są uznawane za wzorzec dla innych tego typu tekstów obecnych w kompozycjach o charakterze apokaliptycznym (Zdun, Pieśni, 12).

35 Odwołania do tekstów qumrańskich w artykule są zgodne z podziałem, jaki zawarty jest w polskim tłumaczeniu tekstów (Muchowski, Rękopisy).

36 אופנים to „koła” znane z wizji Ezechiela (Ez 1,15-21; 3,13; 10,6-19; 11,22) i późniejszych tekstów, gdzie coraz częściej (tak jak tutaj) są jedną z grup aniołów. Muchowski w przekładzie określa ich hebraizmem ofani. Por. Davila, Liturgical Works, 131. 
„podobny do przedmiotów z litego złota ${ }^{37}$, rzucających światto" (כמעשי אופירים מאירי אור; 4Q405 XXIII 2,9-10). Ta charakterystyka duchów jest tak istotna, że oni sami określani są czasem jako oświecający: „formy oświecających ${ }^{38}$ duchów” (צורי רוחות מאירים; 4Q405 XIX,4-5 = 11Q17 XII-XV $6,4)$, co jednak może być metaforycznym odniesieniem do udzielania wiedzy lub mądrości, jak sugeruje tekst 4Q403 I 2,35 („dla rozjaśniających wiedzę”, למאירי דעת). Wśród tych wszystkich niebiańskich postaci można ponadto wyodrębnić grupę, dla której światło jest szczególną domeną - to „bogowie światta” (אלי אור; 4Q403 I 2,35), niewykluczone, że tożsami z „duchami wiedzy i światła” (רוחי דעת ואור; 4Q403 I 1,42 = 4Q405 VI,3). Ponownie występuje tutaj paralelizm pomiędzy wiedzą a światłem, co może być nawiązaniem do mądrościowej symboliki światła, obecnej wcześniej także na kartach Biblii Hebrajskiej ${ }^{39}$.

Kolejnym elementem, na który należy zwrócić uwagę w tej analizie Pieśni jest sam pałac i to wszystko, co go tworzy. Możliwe, że fragmenty tego opisu zawarte są w dwóch uszkodzonych fragmentach tekstu, mówiących o „rzekach światta” (נהרי אור; 4Q405 XV 2 + XVI,2) ${ }^{40}$ oraz o „postaci płomieni ognia" (מראי להבי אש; 4Q405 XV 2 + XVI,3), co jednak jest trudne do zweryfikowania z powodu stanu rękopisu. Pieśń dwunastego szabatu, która najwięcej miejsca poświęca opisowi pałacu Bożego, mówi o uwielbieniu, jakiego doznaje od duchów „majestat świetlanego firmamentu”

37 Dosłownie z Ofiru, kraju słynącego w środowisku biblijnym z wysokiej jakości złota, którego czasem stawał się synonimem (zob. Hi 22,24).

38 Termin מאירים, zdaniem Davili (Liturgical Works, 143), powinien być tutaj odczytany jako rzeczownik „ciała świecące”, znane dobrze między innymi z innych tekstów qumrańskich (zob. np. 4Q392 I,9; 4Q504 VIII), jednak w tej funkcji pojawia się zwykle forma rodzaju żeńskiego מארות.

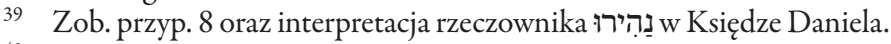

40 Davila, używając odmiennej wokalizacji, tłumaczy to wyrażenie jako „rzeki ognia” (Liturgical Works, 139-140). 
(הוד רקיע האור; 4Q405 XX 2 + XXI-XXII,9), znajdujący się poniżej tronu Pana. Wreszcie tekst z groty jedenastej mówi ogólnie o „świetle światel” (אור אורים; 11Q17 XIX-XX $8,2)^{41}$ panującym w niebiosach oraz o „świetle”, które jest zestawione ze „wspaniałością jego pochwały” (הדר תשבוחותו; 11Q17 XXIII-XXV 10,3-4), jednak luki w tekście nie pozwalają na jego precyzyjną interpretację.

Najistotniejszym jednak określeniem, jakie odnajdujemy w opisie Bożego dworu, jest „doskonałe światło” (אורתום ${ }^{42}$ ), które pojawia się w rękopisach łącznie osiem razy, z tego w dwóch miejscach tekstu Pieśni Ofiary Szabatowej. Najpierw w pieśni siódmego szabatu, mowa jest o "chwale w najdoskonalszym świetle" (הכבוד באור אורתם; 4Q403 I 1,45 = 4Q404 V,4 = 4Q405 VI,6). Drugie wystąpienie zawarte jest w dalszej części tej samej pieśni, jednak poświadczone jest tylko przez jeden manuskrypt (4Q403), gdzie „doskonałe światło” zestawione jest z „barwami ducha najświętszego” (אורתום רוקמת רוח קודש קודשים; 4Q403 I 2,1). Wciąż brakuje jednoznacznej odpowiedzi na pytanie o naturę i tożsamość tego światła. Sam termin jest złożeniem słów „światło” (אור) i „doskonałość” (תום), możliwe, że stanowi on jednocześnie nawiązanie do urim i tummim (האורים והתמים) warto zauważyć, że w zawartych tam opisach niebiańskiego przybytku brakuje charakterystyki Zasiadającego na tronie - jest On wielokrotnie przywoływany w różnych formach leksykalnych, jednak nigdy nie jest opisany. Może to być wyrazem teologicznego przekonania o niedostępności Boga dla człowieka i Jego niewyrażalności za pomocą ludzkich

41 Wyrażenie to może oznaczać również „światło najjaśniejsze” lub „doskonałe", jednak nie wolno go mylić z אורתום.

42 Prawdopodobnie taka jest poprawna pełna pisownia tego terminu, jednak w rękopisach można odnaleźć również warianty (4Q403) oraz אורותם (4Q405). Por. Davila, Liturgical Works, 125.

43 Por. Van Dam, Urim, 86-87. 
słów, które zostało już wcześniej przekazane w opisie tronu z 1 He 14.

Z Pieśniami Ofiary Szabatowej łączą się dwa zależne od tych utworów teksty pochodzące od samych qumrańczyków. Pierwszy z nich to Btogostawieństwa i przekleństwa (4Q286289), będący również kompozycją o charakterze kultycznym, związaną prawdopodobnie z doroczną ceremonią odnowienia przymierza $^{44}$. Pierwszym jej elementem jest blogosławienie Boga poprzez wychwalanie jego niebiańskiego mieszkania. Wychwalane są tam m.in. „fundamenty ognia, płomienie jasności, blaski dostojeństwa, jasności świateł, cudowne źródła światła" מוסדי אש ושביבי נוגה וזהרי הוד נהורי אורים ומאורי פלא);

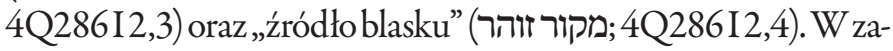
chowanych fragmentach kolejnej części błogosławieństwa dotyczącego aniołów wspomniani są ,aniołowie ognia” (מלאכי אש; 4Q287 II,4) oraz „blask wielobarwny duchów najświętszych” (זוהר רוקמת רוחי קודש קודשים; 4Q287 II,5).

Pod względem formy i treści do Pieśni Ofiary Szabatowej podobna jest też pochodząca ze wspólnoty qumrańskiej Pieśn Mędrca (4Q510-511), która wykazuje zależność od analizowanego wcześniej utworu i od Hodayot ${ }^{45}$. Chociaż tekst zawiera wiele nawiązań do postaci duchów, zarówno dobrych, jak i złych, to niemal zupełnie nieobecna jest w nim metafora światła w interesującym nas kontekście. Raz tylko wzmiankowani są ,,świetliści aniołowie Jego chwały” (מלאכי מאורות כבודו; 4Q511 II 1,8), a do Bożego mieszkania może odnosić się wyrażenie „wieczny ogień płonący” (אש עולמים בוערת; 4Q510 II,4), które jednak znajduje się we fragmencie niepozwalającym na precyzyjną interpretację z powodu stopnia jego uszkodzenia.

Kolejnym utworem, który pomaga zrozumieć wyobrażenie nieba, jakie mieli qumrańczycy, jest inny tekst o charakterze liturgicznym, określany zwykle jako Dzieta Boże, odnaleziony

44 Por. Muchowski, Komentarze, 167.

45 Por. Newsom, „Sectually Explicit”, 181, 183-184. 
w jedenastu fragmentach manuskryptu 4Q392. Utwór ma formę psalmu wychwalającego Boga za Jego dzieło stwórcze, zaś odwołania do światła pojawiają się w pierwszym, największym fragmencie tekstu. Stwierdza on najpierw, że Bóg jest twórcą zarówno światła (אור), jak i ciemności (חשך; w. 4), które uczynił dla siebie.

Kolejne wersety podają jednak zaskakującą informację, że rozdział tych dwóch rzeczywistości jest dokonany jedynie na ziemi, ze względu na człowieka, który potrzebuje cyklu dnia i nocy (w. 6). Tymczasem w niebiańskim przybytku jest zarówno „,najdoskonalsze światto” (אור אורתם), jak i ,wszelki mrok" (כל אפלה), które znajdują się przed Bogiem bez konieczności ich dzielenia (w. 5). Możliwe, że takie zestawienie wiąże się z koniecznością uzgodnienia ścisłego monoteizmu z dualizmem. W ten sposób Pan jest twórcą zarówno światła, jak i ciemności (Iz 45,7), następujących po sobie dnia i nocy (Am 5,8), a nawet duchów światła i ciemności $(1 \mathrm{Q} S 3,25)^{46}$. Bóg i jego najbliższe otoczenie są więc ukazane w tekście 4Q392 jako odzwierciedlenie sytuacji sprzed stworzenia świata, co jest podkreśleniem pierwszeństwa Stwórcy przed stworzeniem. W Księdze Daniela jest On nazwany "Przedwiecznym” (Dn 7,9.13.22), tutaj Jego wieczne istnienie jest symbolicznie przedstawione przez odwołanie do rzeczywistości sprzed rozdziału światła od ciemności opisanego w Rdz 1,4. Warto zwrócić uwagę, że również analizowana wcześniej Pieśńn Ofiary Szabatowej wśród elementów obecnych na dworze niebieskim wymienia „światło i ciemność, i figury” (אור וחושך ובדני; 11Q17 XXIII-XXV 10,4) nik אורתם, z minimalnie zmienioną ortografią, pojawia się

46 Por. Hanson, „Binary Opposition”, 33. Niezależnie od przyjętego w tym artykule podejścia, stanowi on ciekawe zestawienie, ukazujące zmianę dokonującą się w użyciu słownictwa dotyczącego światła i ciemności w badanym okresie.

47 Wspomniane w tekście „figury” kilkakrotnie odniesione są w innych miejscach utworu do postaci duchów niebieskich. 
dwukrotnie w Pieśni, co może wskazywać na powiązanie pomiędzy tymi tekstami.

Autor utworu dodaje ponadto, że z Nim (עמו) jest, „światło, niezbadane i niepoznawalne" (אור לאין חקר ואין לקעת; 4Q392 I,7), co może nasuwać skojarzenia z „niedostępną światłością" w której zamieszkuje Bóg na kartach Nowego Testamentu (zob. 1 Tm 6,16). Podobne określenie możemy znaleźć również w zbiorze Hodayot, gdzie także w kontekście stworzenia ciał świecących i nadania im porządku pada stwierdzenie „z Tobą jest światło” (אתכה אור; 1QH 23,3). Heger, interpretując ten werset, zauważa, że niedostępne ludzkiemu umysłowi światło i zachwyt nad Bożymi dziełami zawarty w drugiej części wersetu zestawione razem wyrażają daremność ludzkich prób zmierzających do przeniknięcia rozumem istoty Boga ${ }^{48}$. Nieco dalej sięga komentarz Nitzan, która twierdzi, że użyte we fragmencie odwołania do światła odnoszą się metaforycznie do Boskiej wiedzy i mądrości, które pozostają niedostępne dla człowieka ${ }^{49}$. O ile przekonanie o niedostępności Stwórcy zawarte w tekście wydaje się rzeczywiście obecne, o tyle ograniczenie jego wymowy tylko do metafory sapiencjalnej jest raczej nietrafione, zwłaszcza przy uwzględnieniu kontekstu, jaki stanowią Pieśni Ofiary Szabatowej i wcześniejsze dzieła judaizmu.

W ostatniej grupie, na którą należy zwrócić uwagę, znajdują się teksty mówiące o światłości jako eschatologicznej nagrodzie sprawiedliwych. Nie odnoszą się one bezpośrednio do omawianego zagadnienia, lecz mogą mieć znaczenie dla dalszej interpretacji, gdyz - podobnie jak to miało miejsce we wcześniej przywołanych tekstach - często jednym z istotnych elementów przemiany świata, jaka dokona się w czasach ostatecznych, jest obecność Boga pośrodku swojego ludu. Stąd też obecność światła jako elementu tej nagrody może sugerować jego związki z mieszkaniem Pana, przynajmniej

49 Nitzan, „Idea of Creation”, 254-256. 
w aspekcie eschatologicznym. Wśród wielu miejsc poruszających to zagadnienie z pewnością należy zauważyć podstawowy tekst wspólnoty qumrańskiej: Regutę Zrzeszenia, mówiący, że sprawiedliwi będą „patrzeć na światło życia” (לאור החיים להביט; 1QS 3,7) i otrzymają „wspaniały majestat w wiekuistej światłości" (מדת הדר באור עולמים; 1QS 4,8). Reguta Wojny ukazuje rzeczywistość eschatologiczną jako rozświetloną przez samego Boga (1QM 1,8-9), a w aramejskim rękopisie 4Q541 przez niektórych włączanym do Dokumentu Lewiego ${ }^{50}$ pada obietnica, że adresat wypowiedzi będzie „radować się w wiecznej światłości” (ותחדה בנהיר עלמא; 4Q541 XXIV 2,6). Wreszcie w Wizjach Amrama mowa jest o tym, że „Synowie Światłości będą świetliści” (לני נהורא) נהירין; 4Q548 I,10) i pójdą „do światłości” (לנהורא; 4Q548 בנירא 4272 $\mathrm{I}, 13)^{51}$. W tym kontekście najbliższy badanej przez nas frazeologii jest fragment jednego z hymnów, który zapowiada, że sprawiedliwi będą stali „w wiecznej siedzibie doskonałego światła" (במכון עולם לאור אורתום; 1QH 21,14). Odwołuje się on zarówno do miejsca przebywania jasności, jak i do pojawiającego się we wcześniej analizowanych tekstach „doskonałego światła”. Oczywiście, przytoczony powyżej wykaz tekstów odnoszących się do eschatologii nie jest wyczerpujący, pozwala jednak dostrzec istotną rolę światła w opisie rzeczywistości ostatecznej oczekiwanej przez qumrańczyków.

Analiza treści zwojów znad Morza Martwego pod kątem ukazania motywu światła używanego dla opisu Bożego mieszkania pozwala dostrzec stopniowe i systematyczne pogłębianie się tej tematyki wraz z rozwojem teologii. Nakreślone w pierwszej części artykułu tło biblijne pozwala lepiej wyodrębnić

50 Por. Muchowski, Komentarze, 260-261.

51 Metafora światła tutaj użyta prawdopodobnie odnosi się do zapowiedzi przyszłego zmartwychwstania, na co wskazują paralele $\mathrm{z}$ innymi tekstami okresu drugiej świątyni, między innymi zawartymi w Dn 12,1-3 czy „Liście Henocha” (zob. przyp. 30). Por. Hogeterp, Expectations, 268, 329. 
nowe elementy wniesione w myśl judaizmu przez pokolenia dysponujące już fundamentem w postaci poszczególnych ksiąg biblijnych, a spisane m.in. w Księdze Jubileuszów i Pierwszej Księdze Henocha. Odczytane w ten sposób tło teologiczne pozwala lepiej zrozumieć teksty zawarte w rękopisach znad Morza Martwego, które jednak niewiele uwagi poświęcają wyglądowi nieba. Jest to tym bardziej zaskakujące, jeśli uwzględni się popularność tego typu opisów w późniejszej literaturze apokaliptycznej. W przeanalizowanych tekstach qumrańskich widać, z jednej strony, zakorzenienie we wcześniejszych tekstach poruszających ten sam temat, zarówno w warstwie terminologicznej, jak i w wykorzystaniu pewnych obrazów charakteryzujących niebiańską rzeczywistość, a z drugiej dokonujący się nieustannie rozwój i pogłębianie myśli teologicznej.

Opisy nieba i znajdującego się tam światła wydają się powiązane $\mathrm{z}$ tradycją mądrościową, jednak interpretacja światła jako mądrości nie wyczerpuje opisów Bożego mieszkania w Qumran. O ile w opisie tronu w Księdze Henocha najważniejszym źródłem jasności jest sam Bóg, o tyle teksty znalezione na Pustyni Judzkiej używają metafory światła do opisania samego nieba i duchów, które je zamieszkują. Światło nie jest tam bezpośrednią emanacją Stwórcy, ale rzeczywistością wobec Niego zewnętrzną, stworzoną, co częściowo może potwierdzać wzmianka o ogniu płonącym przy tronie przygotowanym na czasy ostateczne. Transcendencję Boga wobec stworzenia wyraża również Jego odwieczne istnienie, wyrażone przez odwołanie do rzeczywistości sprzed powstania świata i oddzielenia światła od ciemności.

W ten sposób przeanalizowane teksty, zwłaszcza o charakterze liturgicznym, ukazują światło jako jeden z elementów wyrażających i stanowiących o doskonałości Bożego mieszkania. Jednocześnie ten nadprzyrodzony blask gwarantuje niedostępność niebiańskiego pałacu dla ludzi, podobnie jak miało to miejsce w opisie z $1 \mathrm{He} 14$. To w nim znajduje się światło „najjaśniejsze” i „doskonałe”, dla czło- 
wieka „niezbadane” i „niepoznawalne”, do którego jednak częściowy przynajmniej dostęp można uzyskać poprzez prawe życie, co podkreślają przywołane w ostatniej części artykułu teksty ukazujące światłość jako eschatologiczną nagrodę sprawiedliwych, związaną z nawiedzeniem ludzi przez Stwórcę. Oczywiście, artykuł nie wyczerpuje problematyki rozumienia światła w pismach z Qumran, ale może stać się punktem wyjścia do kolejnych badań, dotyczących także szerszej literatury. Otwarta pozostaje odpowiedź na pytanie o ewentualne qumrańskie tło doksologii z 1 Tm 6 oraz o symbolikę światła poza paradygmatem dualistycznym w zróżnicowanym judaizmie drugiej świątyni.

\section{BibLIOgRAFIA}

Botterweck G.J. - Ringgren H. - Fabry H.-J. (red.), Theological Dictionary of the Old Testament (Grand Rapids, MI: Eerdmans 1974, 1998) I, IX (=TDOT).

Chazon E.G., „Human and Angelic Prayer in Light of the Dead Sea Scrolls", Liturgical Perspectives: Prayer and Poetry in Light of the Dead Sea Scrolls (red. E.G. Chazon) (STDJ 48; Leiden - Boston: Brill, 2003) 35-47.

Collins J.J., Apocalypticism in the Dead Sea Scrolls (LDSS; London - New York: Routelegde, 1997).

Davila J.R., Liturgical Works (ECDSS 6; Grand Rapids, MI: Eerdmans, 2000).

Hanson K.L., „The Dead Sea Scrolls and the Language of Binary Opposition: A Structuralist/Post-structuralist Approach", Australian Journal of Jewish Studies 22 (2008) 26-55.

Heger P., „Another Look at Dualism in Qumran Writings”, Dualism in Qumran (red. G.G. Xeravits) (London - New York: T\&T Clark, 2010) 39-101.

Homerski J., Ksiega Daniela. Wstęp - przektad z oryginatu - komentarz - ekskursy (Poznań: Pallottinum, 2008). 
Hogeterp A.L.A., Expectations of the End. A Comparative TraditioHistorical Study of Eschatological, Apocalyptic and Messianic Ideas in the Dead Sea Scrolls and the New Testament (STDJ 83; Leiden - Boston: Brill, 2009).

Liddell H.G. - Scott R., A Greek-English Lexicon (Revised and Augmented by H.S. Jones) (Oxford: Oxford University Press, ${ }^{9}$ 1925-1940) I-II (=LSJ).

Łach S., Ksiega Psalmów. Wstęp - przektad z oryginatu - komentarz - ekskursy (red. J. Łach) (Poznań: Pallottinum, 1990).

Milik J.T. (red.), The Books of Enoch. Aramaic Fragments of Qumrân Cave 4 (Oxford: Clarendon Press, 1976).

Muchowski P., Komentarze do rękopisów znad Morza Martwego (JiH 1; Poznań: WN UAM, ${ }^{2} 2005$ ).

Muchowski P., Rękopisy znad Morza Martwego. Qumran - Wadi Murabbaiat - Masada - Nachal Chewer (BZ.TNT 5; Kraków: The Enigma Press, $\left.{ }^{2} 2000\right)$.

Newsom C., „Heaven”, Ecyclopedia of the Dead Sea Scrolls (Oxford: Oxford University Press, 2000) I-II, 338-340.

Newsom C., „«Sectually Explicit» Literature from Qumran”, The Hebrew Bible and Its Interpreters (red. W. Propp) (Winona Lake, IN: Eisenbrauns, 1990) 167-187.

Nitzan B., „The Idea of Creation and Its Implications in Qumran Literature", Creation in Jewish and Christian Tradition (red. H.G. Reventlow - Y. Hoffman) (JSOT.SS 319; Sheffield: Sheffield Academic Press, 2002) 240-264.

Parchem M., Biblijny jezyk aramejski. Gramatyka, kompletne preparacje, stownik (BeJ 5; Pelplin: Bernardinum, 2016).

Parchem M., Ksiega Daniela. Wstęp, przektad z oryginatu, komentarz (NKB.ST 26; Częstochowa: Edycja Świętego Pawła, 2008). Rubinkiewicz R. (red.), Apokryfy Starego Testamentu (PSB 13; Warszawa: Vocatio, 1999).

Schiffman L.H. - VanderKam J.C. (red.), Encyclopedia of the Dead Sea Scrolls (Oxford: Oxford University Press, 2000) I-II (=EDSS). 
Scott J.M., On Earth as in Heaven. The Restoration of Sacred Time and Sacred Space in the Book of Jubilees (SJSJ 91; Leiden Boston: Brill, 2005).

Segal M., The Book of Jubilees. Rewritten Bible, Redaction, Ideology and Theology (SJSJ 117; Leiden - Boston: Brill, 2007).

Stokes R.E., „The Throne Visions of Daniel 7, 1 Enoch 14, and the Qumran Book of Giants (4Q530): An Analysis of Their Literary Relationship", Dead Sea Discoveries 15 (2008) 340-358. Szymik S., „Qumran a kanon Biblii Hebrajskiej”, Qumran. Pomiędzy Starym a Nowym Testamentem (red. H. Drawnel - A. Piwowar) (ABL 2; Lublin: Wydawnictwo KUL, 2009) 77-91.

Wróbel M.S., Studia z Ewangelii Janowej (WKS 5; Tarnów: Biblos, 2009).

Van Dam C., The Urim and Thummim: A Means of Revelation in Ancient Israel (Winona Lake, IN: Eisenbrauns, 1997).

VanderKam J., „Book of Jubilees”, Encyclopedia of the Dead Sea Scrolls (Oxford: Oxford University Press, 2000) I-II, 434-438. VanderKam J., „Reflections on Early Jewish Apocalypses”, Apokaliptyka wczesnego judaizmu i chrześcijaństwa (red. M.S. Wróbel) (ABL 6; Lublin: Wydawnictwo KUL, 2010) 13-28. VanderKam J. (red.), The Book of Jubilees. A Critical Text (CSCO 510; Lovanii: E. Peeters, 1989).

Zdun P., Pieśni Ofiary Szabatowej z Qumran i Masady (TzPJ 1; Kraków: The Enigma Press, 1996).

Ks. Mateusz TARGOŃSKi, kapłan archidiecezji lubelskiej, doktorant Instytutu Nauk Biblijnych KUL. Zainteresowania naukowe: literatura okołotestamentalna, a szczególnie teksty z Qumran i targumy. E-mail: targonski.mateusz@gmail.com 